\section{Virgens, viúvas e casadas: representações do feminino no discurso ambrosiano (séc. IV)}

\author{
Virgins, widows and married womens: representations of the \\ feminine in the Ambrosian discourse ( $4^{\text {th }}$ century A.D.)
}

\author{
Larissa Rodrigues Sathler Dias*
}

Resumo: Ao analisar o De Virginibus e o De Viduis, tratados ascéticos escritos por Ambrósio, bispo da Sé de Milão (374-397), este estudo busca compreender não apenas como os corpos das virgens, viúvas e casadas foram representados, mas também averiguar a formação de uma hierarquia feminina dentro da comunidade milanesa. Considerando a posição paradoxal das mulheres no contexto dos discursos morais produzidos pela elite episcopal do século IV, nos quais, por um lado, possuíam certa paridade com os homens, ao menos no plano espiritual, e, por outro, no plano terreno, apresentavam uma infirmitas associada a sua natureza sexual, essa hierarquia se mostra responsável por prever que as virgens e viúvas, mulheres que superaram a debilidade de seus corpos e tornaram-se modelos da castidade cristã, ocupassem uma posição acima das casadas.

\begin{abstract}
In analyzing the De Virginibus and De Viduis, ascetic treatises written by Ambrose, bishop of the Church of Milan (374-397), we sought to understand not only how the bodies of virgins, widows and married women were represented, but also to ascertain the formation of a female hierarchy within the Milanese community. Whereas the women's status in the moral discourses produced by the fourth-century episcopal elite was paradoxical, because, on the one hand, at least on the spiritual level, women were presented in a degree of parity with men, and, on the other, on the ground, infirmitas of the feminine sexual nature stands up, this hierarchy seems to be responsible for foreseeing that virgins and widows, women who overcame the weakness of their bodies and became the model of all Christian chastity, occupy a position above married women.
\end{abstract}

\section{Palavras-chave: Antiguidade Tardia; Cristianismo; Ambrósio de Milão; Corpo; Mulher.}

\author{
Keywords: \\ Late Antiquity; \\ Christianism; \\ Ambrose of Milan; \\ Body; \\ Woman.
}

Recebido em: 20/03/2018

Aprovado em: 18/05/2018

\footnotetext{
* Mestre em História pela Universidade Federal do Espírito Santo (Ufes), licenciada pela mesma instituição e pesquisadora do Laboratório de Estudos sobre o Império Romano (Leir).
} 


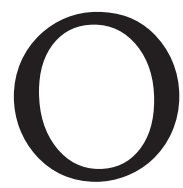
ascetismo feminino se encontrava em franco desenvolvimento nos séculos III e IV. Porém, ainda antes disso, é reconhecida a existência de virgens e viúvas que, ao seguirem os conselhos de Paulo de Tarso, dedicaram-se a uma vida de castidade (CONSOLINO, 1988, p. 33). No Oriente, os testemunhos de Inácio de Antioquia, como a Epistula ad Smyrnaeos (13) e a Epistola ad Polycarpum (V, 2), o Pastor de Hermas, a Apologia Prima (15), de Justino, e a Legatio pro christianis (33), que Atenágoras enviou aos imperadores Marco Aurélio e Cômodo, confirmam, embora vagamente, a existência de grupos de mulheres vivendo em castidade. Quanto ao Ocidente, os tratados ascéticos de Tertuliano e Cipriano de Cartago demonstram que, no século III, a ascese feminina já havia se alastrado pelas congregações do norte da África. Nesta época, a virgindade foi compreendida como um estado autêntico de vida cristã. Todavia, a documentação existente não nos permite afirmar com precisão se as virgens cristãs emitiam desde então um voto público (METZ, 2001, p. 28-35; SERRATO, 1993, p. 19).

Com a chegada do século IV, a realidade é outra. Nesse período, é possível verificar, no Ocidente, não apenas um aumento considerável do número de devotas, mas também a existência de uma cerimônia litúrgica na qual virgens e viúvas emitiam seu voto de castidade. Prova disso são os vestígios deixados por Ambrósio, que, no De Virginibus, descreve como acontecia o ritual de consagração de uma virgem:

\footnotetext{
Vem à nossa memória o caso recente de uma jovem nobre no mundo, agora todavia mais nobre diante de Deus, que, sendo instada por seus pais e parentes a contrair matrimônio, correu para refugiar-se no santo altar, porque, onde melhor poderia fazê-lo uma virgem, senão onde se oferece o sacrifício da virgindade? Porém, não termina aqui sua audácia. Estava junto ao altar de Deus a hóstia da pureza, a vítima da castidade; e colocava sobre sua cabeça a mão do bispo, pedindo a oração; impaciente pelo obrigado atraso, colocava sob o altar a extremidade da cabeça. Acaso, dizia-me, cobrirá melhor o véu que o altar que santifica os mesmos véus? (Ambrósio, De Virginibus, l, 65, grifo nosso).
}

A passagem em questão descreve o rito da uelatio uirginis, uma cerimônia pública que tem como cenário não somente o altar, mas também a presença de uma dezena de virgens vestidas solenemente de branco e do próprio bispo, personagem exclusivamente responsável pela concessão da benção e pela imposição do véu sobre a neófita (NATAL VILLAZALA, 2010, p. 91). Segundo Serrato (1993, p. 31), a cerimônia da uelatio, sobretudo quando se tratava de virgens nobres, além de ser um verdadeiro acontecimento público, marcado pelo reconhecimento da Igreja à dita profissão, era também um meio propagandístico eficaz para captar novas vocações entre as mulheres da comunidade.

Também as viúvas, quando cumpriam os requisitos necessários para uma vida de devoção, realizavam um voto de continência (professio uiduitatis), para conhecimento de 
toda a comunidade. Nesse caso, mesmo que não tenhamos evidências claras de como a professio uiduitatis era anunciada aos demais fiéis, é suposto que em Milão, diferentemente da consagração solene e pública das virgens, o voto das viúvas fosse desprovido de forma e solenidade próprias, embora haja testemunhos de sua regulação no que se refere às condições para efetivar o voto. Sobre isso, Ambrósio afirma que para serem eleitas (qualis autem eligi debeat) as viúvas não teriam que alcançar 60 anos (Ambrósio, De Viduis, 12), muito menos advir de um único casamento (Ambr., Vid., 10), contrariando explicitamente a regra estabelecida em I Timóteo $(5,9-16){ }^{1}$

Mesmo com a ausência de uma cerimônia na qual pudessem tornar público o seu compromisso em conjunto com as virgens milanesas, as viúvas que manifestavam sua vontade em tornar-se uma Deo devoti constituíam, nessa congregação, um setor juridicamente diferenciado dos demais fiéis (SEIJO IBÁÑEZ, 2017, p. 219). Para Dossetti (1940, p. 456), é a aparição do elemento professio que fornece indícios de que algumas viúvas estiveram submetidas a um voto, compondo um grupo jurídico especial dentro das diversas congregações espalhadas pelo Império. No texto de Ambrósio (Vid., 84), é apresentado o termo propositum castitatis, cujo sentido parece ser muito próximo ou idêntico à terminologia professio.

Se a teoria de Dossetti é confiável, o quarto parágrafo do De Viduis consiste na única parte do tratado em que há menção ao termo professio, indicando a oficialidade subjacente à devoção abraçada pelas viúvas milanesas. Em nenhum momento da obra em questão, no entanto, o elemento sacra, termo utilizado para identificar as virgens que haviam passado por um ritual de consagração (METZ, 2001), aparece como algo relacionado ao ritual de profissão de uma viúva. Muito provavelmente isso ocorreu porque o atributo sacra estava intimamente ligado à condição de sacralidade corporal assumida pela virgem consagrada, algo diverso do que ocorria com a viúva, categoria de mulher que hierarquicamente permanecia abaixo da virgem na congregação.

\footnotetext{
${ }^{1}$ No parágrafo 12 do seu De Viduis, Ambrósio afirma não acreditar que o apóstolo pretendia excluir as mais jovens de abraçar a viuvez consagrada. Ao invés disso, dizia o autor, quando Paulo escreveu que é "melhor casar-se do que abrasar-se" (I Coríntios 7, 9), ele estava ditando um remédio contra a debilidade e não uma regra para impedir que as viúvas menores de 60 anos seguissem a castidade. Decerto, Ambrósio sabia que, mesmo baseando-se em Paulo para justificar o celibato das mais jovens, seus fiéis poderiam reconhecer em outra passagem emitida pelo próprio apóstolo, nesse caso I Timóteo (5, 9-16), o contrário daquilo que estava sendo preconizado por ele. Para tanto, a fim de evitar maiores retaliações, utilizou o exemplum de Ana, "viúva octogenária desde a sua juventude e profetisa do Senhor", afirmando que também Paulo conhecia sua história [de Ana] e não pretendeu ignorá-la.
} 


\section{Resistência social em relação à virgindade e à viuvez consagradas}

Mesmo o ascetismo feminino possuindo contornos um pouco mais definidos na segunda metade do século IV - pois contava, ao menos para as virgens, com um rito de consagração oficial -, o discurso de Ambrósio sobre a virgindade e a viuvez enfrentou uma forte resistência social em Milão. Assim, é comum encontrar, no De Virginibus, passagens que apresentam desde uma crítica direta aos familiares até queixas indiretas, nas quais Ambrósio denuncia a falta de conquista de novos frutos para a virgindade em sua própria congregação (Ambr., Virgb., I, 10, 57- 58).

Diversos são os fatores que, na Milão ambrosiana, resultavam em uma baixa acolhida social dos ideais da virgindade. Inicialmente, é preciso destacar que a Península Itálica ainda se encontrava subcristianizada e, por isso, a adoração ativa dos deuses pagãos continuou a fazer parte da vida pública ao menos até as últimas décadas do século IV (BROWN, 1990, p. 282). Nesse caso, podemos conjecturar que a presença do paganismo em amplos setores da sociedade milanesa não facilitava precisamente a compreensão do discurso em favor das virgens cristãs. A própria virgindade abraçada pelas sacerdotisas de Vesta recordava aos fiéis que esse estilo de vida não consistia em algo eminentemente cristão, abrindo brechas para uma competição social e ideológica direta entre ambas as formas de castidade. ${ }^{2}$

Para além dessa provável incompreensão social, advinda da coexistência de modelos variados de castidade em Milão, a resistência à ascese cristã feminina também esteve vinculada ao receio de que a devoção pudesse romper com a instituição familiar. No cristianismo primitivo, a virgindade foi apresentada como uma antítese natural do matrimônio e, por isso, atentava diretamente contra a instituição familiar, minando um

\footnotetext{
${ }^{2}$ Mesmo marcada por diferenças em suas origens, é possível notar algumas semelhanças disciplinares que envolviam a ascese praticada pelas virgens cristãs e as vestais. De acordo com Seijo Ibáñez (2017, p. 251-52), fossem pagãs ou cristãs, as virgens deveriam se vestir de forma simples e sóbria, além de preservarem a modéstia nas demais formas de conduta. Em ambos os casos, se porventura viessem a se relacionar com um homem, corriam o grave risco de serem acusadas pela perda da castidade, embora, nesse caso, o castigo para uma vestal fosse inexoravelmente a morte e, para uma virgem cristã, a penitência e excomunhão da comunidade, assunto que retornaremos mais à frente. Para além dessas semelhanças mais aparentes, Ariel Bybee Laughton (2001), em seu artigo From Vestal Virgin to Bride of Christ, apresenta algumas semelhanças ideológicas que cercam ambas as instituições e lhes conferem identidade em seus respectivos mundos. Em resumo, a autora apresenta quatro paralelismos que tornavam as vestais e as virgens cristãs conceitualmente muito parecidas. O primeiro deles é que, no cristianismo, a virgem tornou-se uma instituição dentro de sua comunidade tão importante quanto as vestais eram para o paganismo. Em segundo, a virgindade praticada pelas vestais e pelas virgens cristãs foi compreendida como um sacrifício pessoal feito para o bem público, isto é, tratavase de um sacrifício canalizado para regenerar o Estado romano e a Igreja, respectivamente. Em terceiro lugar, tanto aquelas que foram levadas ao culto de Vesta quanto as mulheres que escolheram a vida celibatária cristã alcançaram uma série de privilégios que, em geral, não eram concedidos às suas contemporâneas. Em quarto lugar, ambas, na visão de Laughton, não se enquadravam aos papéis tradicionais de gênero, compondo uma nova categoria dentro de suas sociedades, definida pela dessexualização (LAUGHTON, 2001, p. 7-12).
} 
princípio básico da hierarquia social. Como explica Natal Villazala (2010, p. 94-95), é possível que a renúncia sexual tenha sido compreendida pelos romanos como uma forma de rebeldia que rompia com as bases do corpo social, tendo em vista que o matrimônio era, em si, uma representação da hierarquia e da imagem ideal da concordia que devia prevalecer na sociedade.

Como uma instituição socializadora que servia de correia para a transmissão dos princípios de poder, a família era, em resumo, um microcosmo que reproduzia toda a violência e dominação, que garantiam a perpetuação da sociedade. Daí, encontram-se, no texto de Ambrósio, passagens nas quais o bispo enfatizou as perversidades de um matrimônio como forma mais direta de autoridade: "[...] é para isto que levou tantos meses uma filha em vosso seio, para que logo a passe ao poder de um estranho? [...]" (Ambr., Virgb., I, 33), e que, na prática, representava um contrato de compra e venda semelhante à negociação de um escravo: “Em verdade, que miserável é a condição da que vai se casar, levada para o leilão como se tratasse da venda de um escravo, de tal maneira que a leva quem mais dinheiro oferece!" (Ambr., Virgb., l, 56).

Apesar de aparentemente rígido, o discurso ambrosiano acerca do matrimônio foi bastante moderado, uma vez que investir negativamente contra o vínculo familiar poderia acarretar em um risco não apenas para as demais relações hierárquicas do conjunto social, como também para a própria autoridade da Igreja, parte desse conjunto. A este respeito, não há dúvida de que a institucionalização da Igreja foi baseada nas estruturas romanas de autoridade familiar, que, por sua vez, podiam ser justificadas com facilidade pelos Evangelhos e por meio de cenas bíblicas, como a criação de Eva a partir da costela de Adão (NATAL VILLAZALA, 2010, p. 98). Além do mais, não interessava ao bispo milanês enfrentar as famílias da aristocracia local, responsáveis por conceder apoio ao seu episcopado em um momento de conflito com a comunidade ariana. Sendo assim, Ambrósio reconheceu o lugar do matrimônio na Igreja: "portanto, a união matrimonial não deve ser evitada como um pecado" (Ambr., Vid., 89), embora pregasse com veemência que a virgindade estava acima da união conjugal: "assim pois, o matrimônio é digno de honra, porém mais digno de honra é a virgindade" (Ambr., Vid., 12, 72).

Decerto, mesmo que Ambrósio tenha sido muito cauteloso no sentido de não dar a entender que seu louvor à virgindade continha uma recriminação obscura para aqueles que escolhessem o matrimônio, a hierarquia que estabeleceu entre os dois modelos de vida deixava sonoramente clara a posição que buscava para as mulheres nos territórios ocidentais do Império. Contudo, convencer a sociedade milanesa de que a virgindade era o melhor caminho para as suas jovens exigia muito mais do que garantir que o matrimônio não fosse extinto por conta de tal ideal. Na verdade, prezar pela manutenção 
da instituição do matrimônio acarretava uma necessidade ainda maior de convencer a congregação milanesa de que a vocação religiosa estava acima de assuntos econômicos e do próprio parecer do paterfamilias. Importa lembrar que, na Antiguidade Tardia, as alianças matrimoniais eram uma via efetiva de selar acordos político-econômicos, por isso o celibato abraçado pelas virgens e jovens viúvas da aristocracia milanesa poderia colocar em xeque os planos advindos de tais enlaces. ${ }^{3}$

No Ocidente tardo-antigo, as famílias da aristocracia utilizavam o matrimônio como um mecanismo de aliança política, a fim de promover não apenas a ascensão social dos noivos, mas também de seus parentes. Nesse universo, a mulher detinha um papel de protagonista, não necessariamente por si mesma, mas como representante de uma família (VIAL-DUMAS, 2015, p. 145). No caso da viúva, em especial, a economia que envolvia o matrimônio era extremamente importante, tendo em vista que, após o falecimento do marido, ela não apenas poderia ser instituída como sua herdeira, como também, pelo menos até meados do século $V$, recebia por inteiro a doação nupcial (sponsalia), integrada ou não ao dote (LOZANO CORBI, 1993, p. 225), o que a tornava uma pretendente ainda mais desejável em termos econômicos. Em resumo, na lógica social romana, viúvos de ambos os sexos, herdeiros de uma imensa fortuna, eram persuadidos a contrair novas núpcias a fim de reforçar alianças e assegurar a reprodução do patrimônio entre seus pares. No caso de viúvas que não possuíam recursos e necessitavam de um sustento econômico ou, tendo o marido deixado filhos órfãos e ela não fosse capaz de mantê-los, um novo matrimônio poderia diminuir suas dificuldades financeiras (SEIJO IBÁÑEZ, 2017, p. 237).

\section{A ascese cristã como uma via de santificação do corpo feminino}

A recepção fria e hostil imputada pelas famílias milanesas à devoção feminina fez com que Ambrósio lançasse mão de um discurso propagandístico composto pela avaliação de uma série de atributos físicos e morais, responsáveis pela santificação dos corpos das virgens e pela exaltação das viúvas de sua congregação. Diferentemente daquilo que se propôs às fiéis casadas, representadas no discurso ambrosiano como

\footnotetext{
${ }^{3}$ Nas diversas sociedades espalhadas pelo mundo, o matrimônio é uma questão de extrema significação política. Seus encadeamentos sociais como, por exemplo, o mecanismo de aliança, estudados em uma perspectiva antropológica por Lévi-Strauss (1982), bem como suas implicações econômicas, são por demais importantes para ficar exclusivamente à mercê da decisão dos noivos. Como explica Vial-Dumas (2015, p. 144-145), a sociedade ocidental contemporânea é, talvez, uma exceção a esta regra, visto que a supremacia das relações individuais e outras formas de estratégias econômicas tendem a eclipsar o matrimônio como uma via de manutenção do patrimônio da família. Contudo, não se pode afirmar que essa faceta contida na união conjugal tenha sido deixada de lado em favor das uniões puramente sentimentais.
} 
portadoras de uma natureza corruptível (Ambr., Virgb., l, 28), próximas da condição dos escravos (Ambr., Virgb., I, 27; 58; 69), fracas em virtudes se comparadas às continentes (Ambr., Vid., 79) e, às vezes, feias pelo excesso de ostentação (Ambr., Virgb., l, 9, 54), pois inclusive apresentavam, de acordo com o bispo, feridas em algumas partes do corpo devido ao uso exagerado de adornos (Ambr., Virgb, I, 55), as virgens são moralmente consideradas santas por Ambrósio (Ambr., Virgb., I, 51; II, 27; 6, 39) de corpo e espírito (Ambr., Virgb., I, 23; 26; Ambr., Vid., 1, 1), puras (Ambr., Virgb., I, 31; 60; 65; III, 13), estéreis de corrupção (Ambr., Virgb., I, 31), racionais (Ambr., Virgb., I, 31), honradas (Ambr., Virgb., I, 7. 32), pudicas (Ambr., Virgb., I, 23; 8, 40; III, 3, 9), trabalhadoras (Ambr., Virgb., I, 8, 40), bem-aventuradas (Ambr., Virgb., II, 18), piedosas (Ambr., Virgb., I, 23), prudentes (Ambr., Virgb., II, 6, 39), fortes em virtudes (Ambr., Vid., 79), belas (Ambr., Virgb., I, 30; 36; 37; 38; 47; II, 4, 22), formosas (Ambr., Virgb., I, 37; 38; 47), além de serem fisicamente imaculadas (Ambr., Virgb., I, 12; 13), castas (Ambr., Virgb., I, 6, 24; 8, 40; 51; 53), admiráveis (Ambr., Vid., 9), íntegras (Ambr., Virgb., I, 39; Ambr., Vid., 26) e seus corpos não serem apenas considerados sagrados (Ambr., Virgb., II, 20), mas também templo de Deus (Ambr., Virgb., II, 18; 26).

De modo semelhante, às viúvas são direcionados alguns dos atributos previstos para as virgens, com exceção daqueles próprios à condição sacra destas últimas. Elas são consideradas, então, santas (Ambr., Virgb., III, 31) de corpo e espírito (Ambr., Vid., 1.1 ; 14, 82), fortes em virtudes (Ambr., Vid., 1, 1; 3, 37; 38; 45; 79), irrepreensíveis (Ambr., Vid., 8), pudicas (Ambr., Vid., 10) e castas (Ambr., Vid., 31) - castidade esta provada por meio dos costumes e não pelo corpo - (Ambr., Vid., 26), embora, em sua maioria, fossem mulheres portadoras de um corpo fatigado e frio pela velhice (Ambr., Vid., 9), marcado por rugas advindas do luto, o que de certo modo lhes facilitava seguir uma vida de devoção (Ambr., Vid., 51).

Toda essa representação que Ambrósio desenvolveu sobre o corpo das devotas cristãs foi influenciada pela somatória do dualismo agudo entre corpo e alma de Plotino, Fílon de Alexandria e Orígenes, ${ }^{4}$ assim como da teologia paulina, cujo princípio é a ideia de que o cristão necessitava transformar seu corpo, passando de um estado carnal para um estado espiritual. Sendo assim, nos tratados ascéticos de Ambrósio é possível perceber uma tendência em identificar a guerra entre o espírito e a carne, presente nos textos de Paulo, com a oposição familiar clássica entre corpo e mente: "[...] a lei do corpo luta contra a lei da mente [...]" (Ambr., Vid., 79); bem como entre alma e corpo: "[...] assim suceda com

\footnotetext{
${ }^{4}$ No De Virginibus, é possível perceber não apenas uma aplicação das ideias de Plotino e do filósofo judeu-helenista Fílon, mas também dos cristãos Orígenes e, principalmente, Atanásio de Alexandria, em sua Epistula ad Virgines (DUVAL, 1974, p. 29-53; LAUGHTON, 2010, p. 32; MORESCHINI; NORELLI, 2000, p. 355; MCLYNN, 1994, p. 57).
} 
nossa alma para que, livre das barreiras do corpo, resplandeça para fora, como a luz da lâmpada colocada no interior" (Ambr., Virgb., III, 7); além de também relacionar os termos alma e carne: "nós [...], depois de havermos retirado as imundícies dos vícios terrenos, purificamos o interior da alma de toda impureza da carne" (Ambr., Virgb., III, 19).

Ao estudar a visão de Ambrósio sobre o corpo, Brown (1990, p. 288) propôs que o bispo de Milão não apenas encarava o corpo como um espaço perigoso para a alma, mas considerava que somente por meio de Cristo os fiéis poderiam "trocar a carne enfraquecida [...] pela carne 'reformada', uma carne aperfeiçoada por ter sido tomada, em Cristo, pelo próprio Deus". De fato, no texto de Ambrósio (Ambr., Virgb., III, 24, grifo nosso), vemos que somente uma vida em Cristo, adquirida a partir do batismo e mantida, principalmente, pela continência, garantia ao corpo do fiel a saúde espiritual:

[...] porque assim como um corpo enfermo é cuidado, seja com remédios quentes, ou com outros frios, e a troca de medicamentos, quando feita sob prescrição do médico resulta em algo saudável, porém se é feita contra sua prescrição agrava a enfermidade, assim também tudo o que depende de Cristo, nosso médico, é remédio, e tudo o que seja contrário é um dano.

A chave para a compreensão do poder transformador de Cristo, ainda de acordo com Brown (1990, p. 289), estava em seu nascimento virginal, ou seja, era o nascimento assexuado, bem como o corpo imaculado de Cristo, que funcionaria para o bispo como uma ponte entre o estado decaído do corpo humano no presente e sua gloriosa transformação futura na ressurreição. Nesse sentido, o corpo de Cristo, não maculado pela dupla mancha da origem sexual e dos impulsos sexuais, representava simultaneamente o corpo humano antes da Queda e aquele que habitaria o futuro Reino de Deus. Mais que isso, em relação à ascese feminina, Cristo, por seu nascimento virginal, foi apresentado por Ambrósio (Virgb., I, 13; I, 21, grifo nosso) como autor e modelo da Virgindade:

Depois que o Senhor, entrando neste corpo, alcançou a união da divindade e da humanidade, sem qualquer mancha de confusão impura, esse tipo de vida celestial [a virgindade] se espalhou por todo o mundo em corpos humanos. Esta é a nova linhagem, prefigurada pelos anjos que serviram a Cristo na Terra e que serviria ao Senhor com a oferta de seu corpo imaculado. Esta é a milícia celestial que prometeu o exército de anjos quando eles vieram a cantar na Terra. Temos, por implicação, a antiguidade do testemunho desde o início dos séculos, a plenitude da profissão de Cristo.

Que coisa é a castidade virginal, senão a pureza isenta de toda mancha? E a quem podemos considerar seu autor senão ao imaculado filho de Deus, cuja carne não viu a corrupção e cuja divindade não experimentou a impureza? Veja quantos são os méritos da virgindade. Cristo existe antes que a Virgem, Cristo nasce de uma virgem, nascido certamente do Pai, antes dos séculos, porém nascido pela virgem para o bem dos séculos. 
Ao falar sobre a virgindade, portanto, Ambrósio certificou a sua congregação de que Cristo era o caminho para uma nova vida, ao mesmo tempo que fez das virgens o modelo de seres cujos corpos foram transformados por meio d'Ele. Isso não significa afirmar que a transformação do corpo fosse algo promovido exclusivamente pela ascese praticada pelas virgens, pois, como o próprio Ambrósio destacou em seu De Sacramentis (II, 2, 8), "[...] pelo sacramento do batismo, quando nós estamos mortos pelo pecado, renascemos para Deus e somos transformados". Todavia, somente as virgens, por intermédio do sacrifício diário de seus corpos, ${ }^{5}$ passavam, na concepção do bispo, por uma transformação que lhes garantia, ainda na vida terrena, gozar de um estado corporal sacro. Em outros termos, apenas a ascese virginal permitia às mulheres ultrapassar sua natureza, designada como fragilior (Ambr., Virgb., I, 16) e infirmita (Ambr., Vid., 44; 51), e compartilhar de uma natureza divina.

Para melhor compreender a sacralidade corporal alcançada pelas virgens, é elucidativa a explicação de Carmen Álvarez Alonso (2003), para quem a virgem cristã consagrada, devido à sua condição imaculada, acabava por participar de uma natureza menos humana e mais conatural e conforme a Deus. Segundo a autora (ÁLVAREZ ALONSO, 2003, p. 474 e ss), a virgindade foi compreendida por Ambrósio como algo estruturalmente pertencente ao ser do Deus Uno, em cada uma das suas três pessoas divinas. A partir disso, todas as demais formas humanas de virgindade são expressões mais ou menos diretas dessa "virgindade trinitária" que tomou forma e expressão humana em Cristo.

Ambrósio certamente não foi o primeiro a defender essa forma de pureza do ser divino, uma vez que também a encontramos no pensamento neoplatônico de Plotino (Enneades, I, 2, 3). Já entre os cristãos, Gregório de Nissa, em seu De Virginitate (II, 1), menciona a virgindade como uma perfeição própria da natureza divina, podendo esta ser identificada com a pureza essencial e a incorruptibilidade do Espírito Santo, com a incorruptibilidade de um Pai que gerou um Filho sem paixão e com a pureza e impassibilidade da geração do Filho incorruptível. No que se refere a Ambrósio, à apropriação deste tema, que envolve a origem trinitária da virgindade, foi adicionado o desenvolvimento de uma teologia de participação e atuação do ser humano na qualidade virginal, exclusiva do ser divino (ÁLVAREZ ALONSO, 2003, p. 475).

\footnotetext{
${ }^{5}$ Diversas são as menções nas quais Ambrósio aponta a virgindade como uma forma de sacrifício. Dentre elas, destacamse as passagens do De Exhortatione Virginitatis (94), nas quais ele se refere à virgindade consagrada como sacrificium; do De Virginitate (10; 13), em que aparecem os termos sacrificium castitatis e integritas sacrificium, respectivamente; e do De Virginibus (I, 32; 65), em que Ambrósio utiliza as expressões cotidianum sacrificium e sacrificium uirginitatis. Ademais, sacrificium é uma palavra usada indistintamente para falar da virgindade e do martírio físico, tanto no De Virginibus (II, 29) quanto no De Exhortatione Virginitatis (82).
} 
Em resumo, para Álvarez Alonso (2003, p. 484), o bispo milanês presumiu que era por meio da ação transformadora e divinizante do Espírito Santo que a virgem consagrada prolongava e atuava nela mesma o mistério da virgindade humano-divina de Cristo. De fato, no parágrafo 37 do primeiro livro do De Virginibus, Ambrósio afirma que, semelhante ao fogo que transforma o metal em ouro, dando-Ihe brilho e valor próprios, no Espírito Santo a virgindade se faz mais preciosa e adquire sua forma divina:

Considerai quão grandes riquezas o Espírito Santo vos entrega, segundo o testemunho da Sagrada Escritura: o reino, o ouro e a beleza. O reino, porque é a esposa do Rei eterno e porque, com invencível coragem, não te deixas arrastar pelas seduções dos prazeres, mas as domina como rainha. $O$ ouro, porque como esse metal, sob a ação do fogo, torna-se mais precioso, assim a aparência do corpo virginal [species corporis virginalis], consagrada ao Espírito Santo, adquire um aumento da sua forma divina [divino formae suae]. Quem pode avaliar beleza superior à da amada do Rei, daquela a quem o Juiz louva, daquela que é consagrada ao Senhor e devotada a Deus? Sempre esposa e sempre virgem, de modo que o amor não tem fim, nem o pudor perde seu brilho (grifo nosso).

A passagem em questão demonstra o modo pelo qual, na visão de Ambrósio, a virgem consagrada tomava uma representação corporal próxima da divindade cristã. Ambrósio propunha que a ação do Espírito Santo na alma transformava qualitativamente a species corporis virginalis, dando-Ihe sua própria forma (formae suae). Assim, porque essa virgindade é species da verdadeira virgindade prevista na e pelo Espírito Santo, torna-se, sobretudo, divina, permitindo, então, que a virgem participe ontologicamente da divindade cristã, na medida em que perde sua forma corporal humana e assume uma nova forma, própria do Deus Uno.

Prever que a virgindade fosse algo particular da divindade trinitária significava conceder àqueles que dela compartilhavam uma representação digna e superior à natureza humana. Para tanto, Ambrósio (Virgb., I, 48; I, 52, grifo nosso) se valeu também do simbolismo da vida angélica para representar a natureza celestial das virgens:

E posto que é digna de ser comparada não mais aos seres humanos, senão aos celestiais, cuja vida vive já na terra, recebe os preceitos do Senhor para que os guarde $[\ldots]$.

Porém, seguirei toda vida elogiando a castidade? A castidade há feito também anjos. O que a guardou é um anjo e o que a perdeu é um diabo. [...] E que direi da ressurreição, cujos privilégios já possui nesta vida? Pois na ressurreição, nem os homens tomarão mulheres, nem as mulheres tomarão maridos, senão que serão como anjos no céu. O que a nós se promete, a vocês [às virgens] já se concede, e o que em nós são desejos, em vocês uma realidade. Vocês são deste mundo, porém não estão nele. $\mathrm{O}$ mundo mereceu tê-las, porém não pode possuí-las. 
A figura simbólica dos anjos como representação das virgens consagradas se difundiu consideravelmente entre os escritos dos Padres da Igreja e, por obter um grande êxito como alegoria, sempre que era necessário chamar a atenção dos fiéis para a sacralidade das virgens, ela foi reforçada. Sendo assim, no século IV, João Crisóstomo (De Sacerdotio, III, 17) já certificava, no Oriente, que a virgindade aproximava os seres humanos dos anjos, ao passo que Ambrósio foi ainda mais eficaz nesse sentido ao ultrapassar a ideia de proximidade para afirmar ipsis litteris que "a castidade há feito também anjos", como revela a passagem acima. ${ }^{6}$

Como apresentado no De Virginibus $(1,11 ; 1,52)$, a virgindade é vida angélica sobre uma dupla consideração: ela tem sua origem no esposo das virgens, Senhor dos anjos, e ela se projeta em um futuro escatológico. Sobre a segunda dessas considerações, é importante destacar que, anos mais tarde, Ambrósio reforçou, em seu De Virginitate (27), que aqueles que desprezam a vida angélica antecipada pelas virgens desprezam também a realidade escatológica da ressurreição, na qual todos seriam como "anjos no céu". Ademais, essa mesma relação foi expressa por Ambrósio (Virgt., 73), quando o autor utilizou a metáfora do perfume, retirada do livro de Cânticos, para afirmar que o corpo da virgem exala o perfume da ressurreição.

A associação que Ambrósio (Virgb., I, 16; III, 35; Vid., 44; 51) propôs entre as virgens e os anjos não apenas visava a garantir aos demais cristãos que elas eram representantes da vida celestial na terra, projetando aqui um futuro escatológico, mas também que eram criaturas que conseguiram ultrapassar as barreiras da natureza, o que significava, em essência, dizer que as virgens eram seres que extrapolaram sua própria condição humana, rompendo com a "debilidade natural" atribuída ao sexo feminino.

Como já mencionamos, no De Virginibus e no De Viduis, a natureza sexual feminina foi apresentada como débil (infirmitas). De acordo com Paola Francesca Moretti (2014), a representação do gênero feminino, nos discursos de pensadores cristãos, a exemplo de Tertuliano, Cipriano, Ambrosiaster, Ambrósio e Jerônimo, foi estabelecida de forma paradoxal, uma vez que variou entre o reconhecimento da aequalitas entre os sexos, em uma glória futura, e a infirmitas do sexo feminino, no plano da realidade efetiva. De modo geral, na visão da autora (MORETTI, 2014, p. 146), esse discurso paradoxal foi calcado, por um lado, nos relatos da criação contidos em Gênesis (1-3), cuja exegese dependeu da atribuição ou negação da mulher como imago Dei; e, por outro, de algumas seções do corpus paulino, que afirma tanto um estatuto de subordinação da mulier em

\footnotetext{
${ }^{6}$ De acordo com Ramos-Lissón (1999, p. 25), subjaz à afirmação ambrosiana de que a castidade há feito anjos uma exegese de Gênesis $(6,2)$, segundo a qual a queda dos anjos foi devida a um pecado sexual. Nesse caso, os anjos que guardaram a castidade conservavam um estado de vida paradisíaco, que, por sua vez, é o mesmo vivido pelas virgens na terra.
} 
relação ao uir, como a equivalência mulier/uir em relação a Deus. ${ }^{7}$ Em Ambrósio, um discurso dicotômico pode ser observado, na medida em que são associadas à explícita subordinação da esposa ao marido, em esporádicas afirmações - baseadas em 1 Coríntios $(7,4)$ - de uma reciprocidade de sujeição entre ambos os sexos (Ambr., Vid., 69).

No entanto, essa variação na forma de perceber a mulher laica, ainda que importante para repensar a ideia de que os Padres da Igreja direcionaram a elas retratos exclusivamente negativos, não pode ser tomada como parâmetro para uma suposta existência de paridade entre os sexos nas comunidades do século IV. Nesse caso, e nisso concordamos com Moretti (2014, p. 182), é necessário sublinhar a primazia de um marco antropológico que segue, ainda na época cristã, construído sobre sólidas categorias conceituais e sociológicas que, no plano da realidade efetiva, como também na esfera da metáfora, concentram no masculino uma soma de valores positivos, enquanto ao feminino é imposta uma série de elementos negativos.

Embora no De Virginibus e no De Viduis, Ambrósio não comente diretamente o motivo que leva a mulher a ocupar uma posição subalterna em relação ao homem, sabese que, na Antiguidade Tardia, o pensamento dos cristãos, incluindo aquele relacionado à mulher, estava permeado pelas inúmeras interpretações que se faziam do Pecado Original. Tais interpretações se encontram representadas não apenas nos documentos da época, mas também em diversos edifícios e monumentos funerários, a exemplo da Figura 1 , onde a mulher pode ser percebida ao lado da serpente, na cena em que ela e o homem estão sendo conduzidos pelo Filho de Deus para fora do Paraíso.

Em Ambrósio, a ligação entre a inferioridade da mulher e o Pecado Original pode ser encontrada em sua obra De Paradiso, bem como em algumas passagens do De Virginitate e do De Institutione Virginis. No De Paradiso $(4,24)$, a distinção entre homem e mulher é discutida a partir da consideração dos lugares onde cada um havia sido criado. Nesse caso, à primeira vista, se poderia conjecturar que a mulher é hierarquicamente superior ao homem, uma vez que foi formada dentro do paraíso, ao passo que o homem foi criado fora e, somente depois, colocado ali. Contudo, o próprio Ambrósio (Parad., 4, 24) deixa claro que este não é um motivo para fazer da mulher um ser superior ao homem, tendo em vista que "[...] não pelo lugar, nem pela nobreza de origem, senão pela virtude, cada

\footnotetext{
${ }^{7}$ Dentre as seções do corpus paulino que justificam a submissão da mulher em relação ao homem estão: 1 Cor. $(11,8)$ e 1 $\operatorname{Tm}$. (2,13), prioridade do homem na criação; 1 Cor. $(11,7)$, o homem é a imagem e glória de Deus e a mulher é glória do homem; 1 Cor. $(11,3)$ e Ef. $(5,21-23)$, o homem é a cabeça da mulher; $1 \mathrm{Tm}$. $(2,14)$, responsabilidade de Eva pelo Pecado Original; 1 Cor. $(14,33-36)$ e $1 \mathrm{Tm}$. $(2,11-12)$, obrigação das mulheres em guardar o silêncio; Col. $(3,18)$ e Ef. $(5,22)$, submissão da mulher em relação ao homem. Já aquelas que justificam um ideal de igualdade são: Gl. (3, 27-28), abolição pós-batismal da distinção entre os sexos; 1 Cor. $(11,11-12)$ e 1 Cor. $(7,4)$, afirmação da reciprocidade de sujeição.
} 
um tem graça para si. Em resumo, foi feito fora do paraíso, isto é, em um lugar inferior [...]; e ela, que em melhor lugar está, isto é, foi feita no paraíso, foi imaginada inferior".

Figura 1 - Representação do Pecado Original no sarcófago intitulado Dogmático, séc. IV

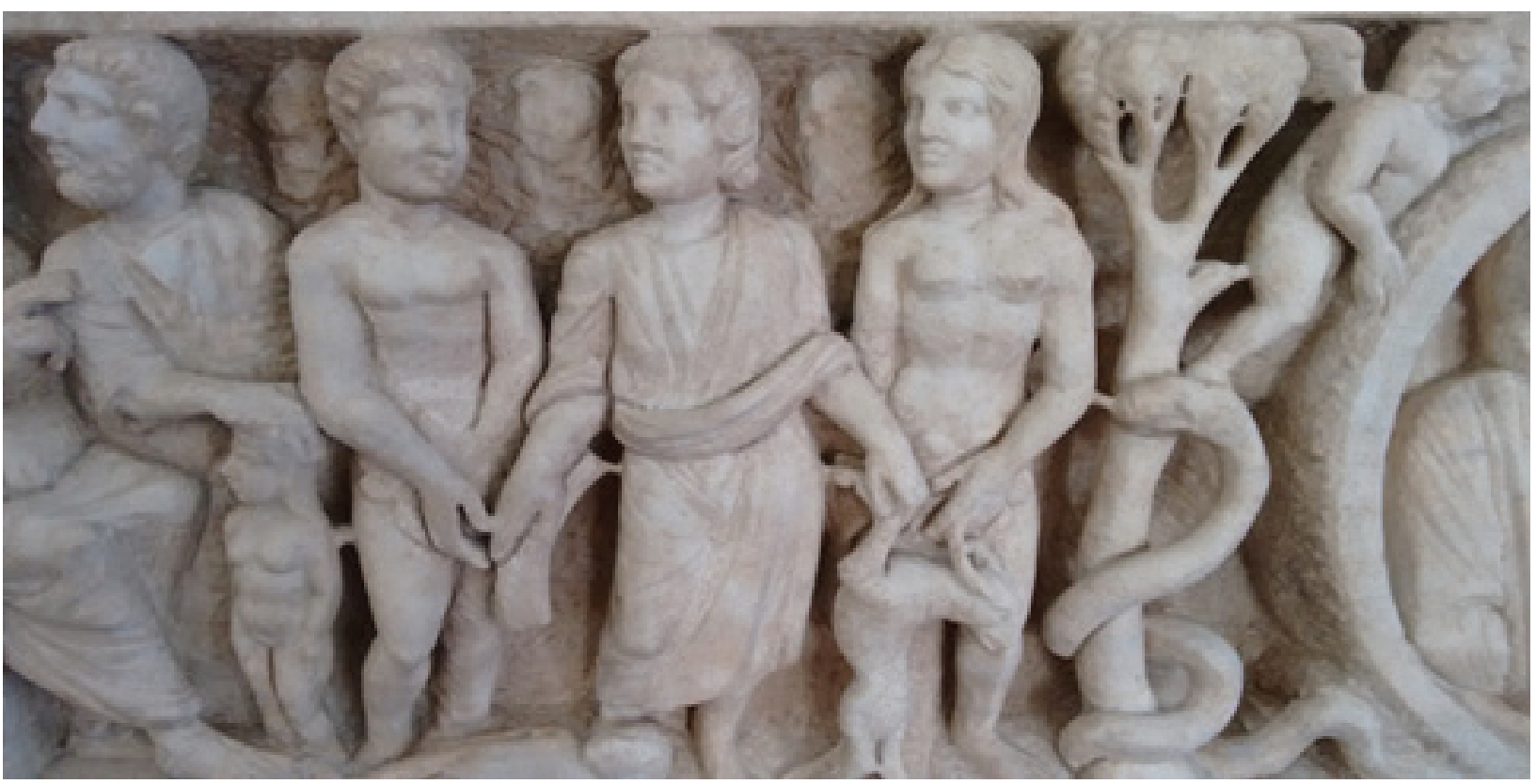

Fonte: Museu do Vaticano. Acervo pessoal da autora (2016).

De modo geral, essa inferioridade feminina se depreende do fato de que Eva foi enganada pela serpente e enganou o homem. Assim, na mesma obra, Ambrósio (Parad., $12,56)$ diz que a Eva se atribui maior culpa no Pecado Original, pois afirma que o próprio "sexo poderia mostrar quem podia errar primeiro", ou seja, o sexo feminino, que é o sexus infirmior, "o sexo mais débil" (Ambr., Parad., 14, 70). Logo em seguida, Ambrósio (Parad., 15, 73) retoma a imagem da serpente como associada ao prazer (delectatio). Quanto à mulher, ela é relacionada ao sensus (sentido); no que diz respeito ao homem, à mens (mente). $\mathrm{O}$ bispo conclui, então, que a culpa mais grave é da serpente, seguida da mulher e só depois do homem. Nesse contexto simbólico, em que se distingue o feminino (sensus) do masculino (mens), a mulher, herdeira de Eva, foi culpabilizada por ter se rendido à tentação da serpente, pois, se ela, na condição de "sentido", tivesse permanecido em alerta, não teria comprometido a humanidade com seu pecado, evitando que esta perdesse sua condição imortal (Ambr., Parad., 2, 11).

Em resumo, a visão que Ambrósio apresentou do feminino em seu De Paradiso (10, 47) é a de que foi a mulher quem arrastou Adão até o pecado, daí sua reprodução como complemento do homem não ter sido uma coisa boa. Similarmente, no De Virginitate, Ambrósio relaciona a disciplina imposta às mulheres, nesse caso o silêncio, e a culpa de 
Eva pelo Pecado Original. Em outros termos, isto significa que, para o prelado milanês, a disciplina direcionada ao corpo feminino é justificável a partir do comportamento errôneo de Eva:

\begin{abstract}
Se a porta de Eva tivesse fechada, nem Adão teria sido enganado, nem [Eva] haveria respondido à serpente que lhe perguntava. A morte entrou pela janela, isto é, pela porta de Eva. A morte entra por tua porta, se falas com falsidade, se falas de modo torpe, atrevida, enfim, se falas quando não convém. Assim pois, estejam fechadas as portas de teus lábios e fechado o vestíbulo de tua voz. Então, talvez deverás reabrir, quando ouvir a voz de Deus, quando escutar ao Verbo de Deus (Ambr., Virgt., 81).
\end{abstract}

Também aos corpos femininos Ambrósio lançou uma série de deméritos, cujos princípios já eram propagados entre os médicos e filósofos pagãos do século II, mas que, entre os autores da Patrística, como é o caso do bispo milanês, estiveram estreitamente vinculados ao erro de Eva. Dentre os deméritos apresentados no De Virginibus e no De Viduis estão as moléstias advindas de numerosos partos (Ambr., Virgb., l, 25) e o peso da criação dos filhos (Ambr., Virgb., l, 26), ambos consequências da atividade sexual à qual as esposas, diferentemente das virgens, estavam sujeitas. A respeito disso, convém recordar que, para Ambrósio (Exposito In Lucam, IV, 6), embora a Queda não tenha sido motivada por um pecado sexual, mas sim pela desobediência à ordem de Deus, o matrimônio e tudo que dele advém, incluindo a união sexual, o parto e os filhos, são resultantes do primeiro erro. Dessa forma, entender que Eva foi culpada pela desobediência do casal significava prever também que o despojo da virtude do corpo humano, leia-se a chegada do prazer sexual à Terra, adveio da falta por ela cometida.

Todas essas representações da mulher, ligadas à figura de Eva, justificavam para os cristãos, incluindo Ambrósio, a infirmitas da natureza feminina se comparada à masculina. Mais que isso, a partir da noção de que o sexo entrou no mundo por Eva, considerouse que as demais mulheres fossem portadoras de uma natureza carnal, sendo elas reconhecidas como uma tentação (tentatio) para o homem (Ambrósio, De Institutione Virginis, 30-31). Ademais, a natureza frágil das mulheres fica subtendida em passagens nas quais é identificada nelas, com exceção das virgens que, pela falta da união sexual, são portadoras de uma natureza incorrupta (Ambr., Virgb., I, 8, 40), uma forte propensão aos vícios. Daí Ambrósio denunciar que a mulher casada, pela fragilidade da sua natureza, corrompe o seu próprio corpo por meio de atos como se pintar, falsificando sua natureza para agradar ao marido ((Ambr., Virgb., l, 28), gastar excessivamente com roupas e joias, a fim de comprar sua beleza ((Ambr., Virgb., I, 29), além de ferir e aprisionar seus corpos 
com adornos, o que as torna, aos olhos do bispo, mais miseráveis que os indivíduos condenados ao cárcere ((Ambr., Virgb., l, 55).

Essas posturas e hábitos de corrupção contra o corpo fizeram com que Ambrósio representasse as esposas não apenas como uma categoria de mulher fisicamente menos bela que as virgens, mas também moralmente mais feias:

Veja a essa [a esposa] que se arranja para agradar [ao marido], como anda toda composta, como se fosse a um cortejo processional, chamando a atenção e atraindo aos olhares de todos; é mais feia precisamente por isso mesmo, pelo que tenta agradar, posto que o desprezo popular é atraído antes que o ato de agradar ao marido. Em vocês [as virgens], em troca, é mais conveniente a despreocupação pelo cuidado da beleza, e o melhor ornamento é esse mesmo descuido em se adornar (Virgb., I, 9.54, grifo nosso).

Diferentemente das casadas, a beleza e a formosura das virgens consagradas advêm do fato de sua alma não ser manchada pela sociedade terrena, ou seja, pelos desejos terrenais, e nem tampouco pela mácula das relações sexuais:

Vocês, por outro lado, virgens ditosas, que não conhecem a estas coisas que são mais tormentos que adornos; vocês que têm o rosto coberto, não prestam atenção aos olhares dos homens e não apreciam seus méritos segundo o engano do erro alheio. Certamente lutam por conseguir sua formosura, não do corpo, senão da virtude, que nem o tempo esgota, nem a morte destrói, nem nenhuma enfermidade pode corromper. Sobre esta beleza, só Deus é o único juiz, quem ama as almas belas, ainda que estejam em corpos não tão belos. A virgem não conhece o peso da gravidez, nem as dores do parto, e sem dúvida, sua descendência é mais numerosa, porque se reproduz em espírito e a todos considera como filhos. É fecunda em descendentes, estéril às perdas familiares e tem herdeiros sem conhecer o luto (Ambr., Virgb., I, 30, grifo nosso).

Esta [a beleza da virgem] é, sem dúvida, a verdadeira beleza, a que nada falta e a única que merece ouvir as palavras do Senhor: Você é toda formosa, amiga minha, e não há em ti defeito algum. Vem aqui do Líbano, esposa minha, vem aqui do Líbano: passará e retornará a passar desde o princípio da fidelidade, desde os cumes de Senir e do Hermom, desde os esconderijos dos leões, desde os montes dos leopardos. Com tais manifestações, nos é mostrado a perfeita e irrepreensível formosura da alma virginal, oferecida nos altares divinos, entre os ataques e ciladas das feras espirituais, sem dobrar-se nas coisas morais, senão que sempre pendente dos mistérios de Deus, tem merecido ao amado, cujos peitos estão cheios de alegria: pois o vinho alegra ao coração do homem (Ambr., Virgb., l, 38, grifo do autor).

Essa polarização que Ambrósio criou em torno das virgens e das casadas permite conjecturar que apenas a primeira categoria de mulher, cujas paixões do corpo estão mortas (Ambr., Virgb., I, 39), conseguiu romper com a herança de uma natureza débil, advinda de Eva. Ao passo que a segunda categoria, ainda que representada pela grande 
maioria das fiéis, não alcançava a transformação de sua natureza, uma vez que se mantinha presa ao domínio do marido e às ataduras da obrigação carnal (Ambr., Vid., 81).

Apesar de estarem impedidas de transformar a natureza de seus corpos, suprimindo a "inferioridade congênita" que era considerada própria do corpo feminino (CONSOLINO, 1988, p. 35), as esposas cristãs podiam salvar-se quando, após a morte do marido, elas decidiam abraçar o estado de viuvez ao invés de contrair novas núpcias. De fato, nos tempos de Ambrósio, as viúvas cristãs foram consideradas indivíduos cujo estado corporal era similar, mas não idêntico, ao das virgens consagradas. Nesse caso, entendia-se que também as viúvas, por meio da experiência de uma vida de santidade, marcada pelo abandono das relações sexuais, poderiam superar a debilidade do sexo feminino.

Ainda que a viúva não pudesse exaltar a sua integridade física, muito menos ser considerada uma verdadeira forma de hierofania, ${ }^{8}$ sua transformação corporal e consequente prestígio junto à comunidade se davam na medida em que ela renunciava a um prazer cujos atrativos conhecia bem:

[...] uma vez que temos tratado, nos três livros anteriores, de elogiar as virgens, passemos a falar das viúvas. Não devemos deixar de honrar, excluindo-as do elogio das virgens, as que a palavra do apóstolo uniu com as virgens, segundo o que está escrito: $A$ mulher não casada e a virgem pensam nas coisas que são do Senhor, para serem santas de corpo e espírito. Pois, de certo modo, a doutrina sobre a virgindade se robustece com os exemplos das viúvas. As que em união com o marido, guardam o tálamo casto, são um exemplo para as virgens que devem guardar sua pureza para Deus. E talvez não é menos virtuoso absterse do matrimônio, uma vez que conhecem seus deleites, que ignorar esses prazeres. As viúvas são fortes em ambos os aspectos, de tal maneira que não se arrependem do matrimônio, ao qual se mantém fiéis, e não são prisioneiras dos deleites conjugais, para que não pareçam débeis [uideantur infirmae], incapazes de governarem a si mesmas (Ambr., Vid., 1, 1, grifo do autor).

Na passagem em questão, vê-se que, para Ambrósio, a virtude da viúva consagrada quase alcançava a das virgens, já que, tendo experimentado os prazeres carnais, ela era capaz de ignorá-los e manter a sua castidade. Assim, livre do jugo conjugal, a viúva demonstrava duplamente a sua fortaleza: primeiro, por ter se mantido fiel durante o matrimônio e, segundo, por abster-se de novas relações. Para justificar sua forma de pensar, o bispo de Milão argumentava que, se as virgens e as viúvas foram unidas pelas

\footnotetext{
${ }^{8}$ Ao analisar as homilias de João Crisóstomo acerca das virgens, Ventura da Silva $(2011$, p. 43) diz que a aparição de uma virgem em público seria uma verdadeira manifestação do sagrado, podendo produzir sobre a audiência um forte impacto. Para Mircea Eliade (2012, p. 17), a manifestação tangível do sagrado é chamada de hierofania e a história das religiões está repleta desse fenômeno. Seja de forma elementar ou complexa, as hierofanias revelam algo que não pertence ao mundo profano. Logo, podemos conjecturar que, ao serem consagradas, as virgens não eram mais reconhecidas como simples devotas, mas como hierofanias, pois seus corpos passavam a representar, dentro da comunidade, algo que já não era humano, mas divino.
} 
palavras de Paulo (I Coríntios 7, 34), estas últimas também deveriam ser devidamente dignas de reconhecimento. Dessa forma, na medida em que prevaleciam num estado de continência corporal, as viúvas tornavam-se, aos olhos de Ambrósio, indivíduos cuja natureza era considerada irrepreensível, motivo pelo qual deviam ser honradas também pelos bispos (Ambr., Vid., 8).

O grau de hierarquia estabelecido entre as mulheres da congregação milanesa estava tão intimamente relacionado à prática sexual que, no que se refere a este aspecto, Ambrósio chegou a considerar que algumas viúvas deveriam ser mais honradas do que outras:

Na realidade, se alguma contrai segundas núpcias, certamente os preceitos do apóstolo não as condenam, e se encontram novamente livre após a morte do marido, não está proibida de abraçar a viuvez, como se houvesse perdido o fruto do pudor. Nela estará incluso o mérito de uma castidade tardia, porém será mais reconhecida a que não contraiu um segundo matrimônio. Em efeito, naquela [que não voltou a se casar] é sobressalente o amor à castidade, nesta a velhice e o pudor parecem haver posto um limite às núpcias (Ambr., Vid., 10, grifo nosso).

Em outros termos, supõe-se que, para o prelado milanês, as viúvas que contraíssem um único matrimônio, por terem abdicado dos prazeres carnais há mais tempo, deveriam ser mais reconhecidas do que aquelas que contraíssem novas núpcias e só tardiamente, pelo cansaço do corpo, abraçassem a castidade.

O consentimento de Ambrósio em consagrar viúvas que não haviam sido esposas de um só marido (uniuira) pode ser explicado pela ideia de que, em uma sociedade tão tradicional como a milanesa, o bispo se deparava com uma considerável dificuldade em atrair novas viúvas para o estado devocional. Logo, mesmo tendo em vista que o modelo de viuvez cristã era Ana,

[...] mulher de um só marido e que também é confirmada pela idade avançada, cheia de vida pela piedade religiosa e já diminuída no vigor do seu corpo, cujo lugar de alojamento é o templo, seu colóquio é a oração, sua vida é o jejum; a que com sua devoção obsequiosa e infatigável praticava durante horas do dia e da noite, enquanto conhecia a velhice do seu corpo, não ignorava a idade da piedade. Assim se formou desde sua juventude, assim é louvada em sua velhice cheia de experiência, a viúva que guardou a viuvez não por razões circunstanciais, nem pela debilidade do corpo, senão pela magnanimidade de sua virtude. Em efeito, posto que se diz que viveu com seu marido sete anos, depois da sua virgindade, certamente confirma que a conservação de sua velhice havia iniciado no zelo da adolescência (Ambr., Vid., 22).

Ambrósio (Vid., 11) não demorou a reconhecer o pudor daquelas que estavam na condição de viúvas pela segunda vez, bem como preconizou que o mérito da viuvez não se limitava exclusivamente à castidade do corpo, mas também à "prática intensa e generosa 
da virtude", leia-se a distribuição de esmolas, a hospitalidade e a piedade (Ambr., Vid., 4, $5 ; 6,11 ; 4,21 ; 29,30 ; 31,54)$. Com essa fala, o bispo ampliava os parâmetros de seleção para o grupo das viúvas, permitindo que mulheres advindas de segundas núpcias e, por isso, "menos castas", fossem aceitas pelo discurso religioso. Pari passu, sob a exigência da prática da "boa obra", garantia-se que importantes doações fossem direcionadas à Igreja, uma vez que economicamente as viúvas da aristocracia possuíam maior autonomia do que as jovens virgens de Milão.

De mais a mais, levando em consideração que a viúva consagrada era um ser híbrido, uma vez que flutuava entre a santidade do corpo da virgem e a corrupção sexual do corpo da casada, se fazia necessário insistir na ideia de que sua castidade podia ser provada por outros meios que não fosse tão somente a conservação da virgindade. Daí Ambrósio (Vid., 26) estipular que, tendo elas perdido a possibilidade de demonstrar sua virgindade, poderiam provar sua castidade "não nas declarações de uma parteira, senão em seus costumes". Em essência, foi por meio desse arranjo retórico que essa categoria de mulher pôde compartilhar junto às virgens a imagem de santas (Ambr., Virgb., III, 31; Ambr., Vid., 1, 1; 14, 82), fortes em virtudes (Ambr., Vid., 1, 1; 3, 37; 38; 45; 79), pudicas (Ambr., Vid., 10) e castas (Ambr., Vid., 26, 31), embora seu status não pudesse ser provado segundo a virgindade, atributo físico indispensável para se alcançar uma natureza divina, mas por um conjunto de costumes que vinculava o abandono do prazer carnal à prática "intensa e generosa das boas obras".

\section{Conclusão}

Desde a Antiguidade, os discursos religiosos contribuem para a construção e naturalização das desigualdades de gênero, legitimando as diferenças entre homens e mulheres, impondo aos corpos sexuados uma identidade determinada e, por meio das relações de poder, verdades sobre eles. Na qualidade de um discurso religioso, os tratados de Ambrósio aqui analisados evidenciam essas desigualdades, na medida em que apresentam a natureza feminina como algo moralmente débil, o que decerto contribuía para justificar o domínio que os homens da congregação de Milão exerciam sobre suas esposas.

Tanto o De Virginibus quanto o De Viduis, discursos nos quais Ambrósio formula a representação das virgens, das viúvas e das casadas, revelam apreensões de mundo próprias do grupo ao qual o bispo pertence. Em outros termos, estes discursos indicam a forma pela qual a elite episcopal, como uma instituição formadora de sentido, percebia os corpos destas mulheres. De modo geral, ao falar da mulher, Ambrósio atendeu ao topos 
de uma literatura cristã que, projetada em autores como Tertuliano (De Cultu Feminarum, I, 1, 1-2) e Cipriano de Cartago (De Habitu Virginum, 17), fez das mulheres herdeiras de Eva e, portanto, portadoras de uma infirmitas natural e propensas ao pecado. Seguindo essa lógica, também foi reconhecido que as relações sexuais só poderiam ter sido introduzidas na terra por meio do erro da mulher, pois, como pensava Jerônimo (Adversus lovinianum, I, 16) e também Ambrósio (Exp. In Lucam, IV, 6), embora o Pecado Original não tenha consistido em um ato carnal ou na vontade de realizá-lo, suas consequências foram cruciais para a entrada do elemento sexual no mundo.

Nessa conjuntura, em que se previa que o sexo estava relacionado, mesmo que indiretamente, à Queda, as mulheres acabaram sendo representadas como indivíduos carnais por excelência. Assim, ficou estabelecido que, para adentrarem no mundo espiritual, elas deveriam rejeitar os elementos definidores de sua natureza, dentre eles o próprio sexo. A consequência dessa medida foi que, para os Padres da Igreja, a virgindade passou a configurar o estilo de vida ideal para as mulheres cristãs, seguido da viuvez e, somente depois, do casamento casto. De fato, o casamento, com a sua dívida carnal, ocupava necessariamente a mais baixa posição nessa hierarquia, cujo parâmetro de definição se dava basicamente pela ausência da prática sexual na vida das mulheres.

De mais a mais, ainda que, no século IV, os discursos em favor da castidade feminina estivessem fervilhando por todo o Ocidente, não é possível afirmar que seus princípios foram formulados de forma homogênea e muito menos recebidos igualmente por todas as comunidades desta região. Como destacado no início deste artigo, em Milão, por exemplo, Ambrósio encontrou uma série de barreiras imputadas pelas famílias de sua congregação à devoção feminina, fato que o levou a sancionar um status de divindade para aquelas que abraçavam a virgindade cristã de forma perpétua. Do mesmo modo, às viúvas consagradas Ambrósio direcionou uma série de atributos que confirmavam a santidade de seus corpos, ao passo que as casadas foram apresentadas como presas aos grilhões do casamento e ao peso dos partos. Ao fazer uma analogia entre o estado conjugal e a escravidão, Ambrósio observou que a esposa, de modo semelhante ao escravo, estava submetida ao domínio de seu marido e, por isso, vivia para agradá-lo. Por outro lado, as devotas, em especial as virgens, libertas das condições matrimoniais, poderiam se dedicar exclusivamente a Deus, garantindo, dessa forma, que seus corpos alcançariam uma transformação plena e, assim, suprimiriam a debilidade própria de sua natureza em prol de uma vida espiritual. 


\section{Referências}

\section{Documentação textual}

AMBRÓSIO DE MILÃO. Explicação do símbolo. Sobre os sacramentos. Sobre os mistérios. Sobre a penitência. Introdução e notas por Roque Frangiotti e tradução por Célia Mariana Franchi Fernandes da Silva. São Paulo: Paulus, 2005.

AMBROSIO DE MILAN. La virgindad, la educación de la virgen y exhortación a la virgindad. Introducción, traducción y notas de Domingo Ramos-Lissón. Madrid: Ciudad Nueva, 2007.

AMBROSIO DE MILAN. Sobre las virgenes y sobre las viudas. Introducción, traducción y notas de Domingo Ramos-Lissón. Madrid: Ciudad Nueva, 1999.

AMBROISE DE MILAN. Traité sur l'Évangile de Saint Luc. Disponível em: <https:// laportelatine.org/bibliotheque/docteurs/AmbroiseMilan/Ambroise_Tome1.pdf>. Acesso em: 20 mar 2018.

ATHENAGORAS. A plea for the Christians. Translated by B. P. Pratten. Disponível em: <http://www.logoslibrary.org/athenagoras/plea/>. Acesso em: 05 fev 2018.

AUGUSTINE. On the Good of widowhood. In: Nicene and Post-Nicene Fathers, series I.

Translated by C. L. Cornish: Christian Literature Publishing, 1887.

BÍBLIA DE JERUSALÉM. Tradução de Ivo Storniolo e de José Bortolini. São Paulo: Paulus, 2002.

CIPRIANO. Obras completas. Introdução, tradução e notas das Monjas Beneditinas da Abadia de N. S. das Graças de Belo Horizonte. São Paulo: Paulus, 2016.

JEAN CHRYSOSTOME. Sur le sacerdoce. Traduit par A-M. Malingrey. Paris: Du Cerf, 1980. GREGORY OF NYSSA. On virginity. In: Nicene and Post-Nicene Fathers, series II. Translated by William Moore and Henry Austin Wilson. New York: Christian Literature Publishing, 1893.

HERMAS. Shepherd of Hermas. Translated by Alexander Roberts and James Donaldson

D. D. Disponível em: <http://www.earlychristianwritings.com/text/shepherd.html>. Acesso em: 01 dez 2017.

IGNATIUS OF ANTIOCH. The epistles of St. Ignatius, bishop of Antioch. Introduction, translation and notes by J. H. Srawley. D. D. New York: Macmillan Company, 1919. v. 2.

JEROME. The principal works of St. Jerome. Translated by W. H. Fremantle, G. Lewis and W. G. Martley. New York: Christian Literature Publishing, 1892. 
JUSTINO. Primeira Apologia. Introdução e notas de Roque Frangiotti e tradução de Ivo Storniolo e Euclides M. Balancin. São Paulo: Paulus, 1995.

PLOTINO. Enéadas. In: BARACAT JUNIOR, J. C. Plotino, Enéadas I, II e III; Porfírio, Vida de Plotino. Tese (Doutorado em Linguística) - Programa de Pós-Graduação em Linguísticva da Universidade Estadual de Campinas, Campinas, 2006.

TERTULLIAN. On the appareal of women. Disponível em: <http://www.newadvent.org/ fathers/0402.htm>. Acesso em: 15 jan 2018.

\section{Obras de apoio}

ÁLVAREZ ALONSO, C. Notas trinitarias para una pneumatología de la virginidad según San Ambrosio. Revista Española de Teología, v. 63, n. 4, p. 471-97, 2003.

BROWN, P. Corpo e sociedade: o homem, a mulher e a renúncia sexual no início do cristianismo. Rio de Janeiro: Jorge Zahar, 1990.

CONSOLINO, F. E. II monachesimo feminile nella tarda antichità. Codex Aquilarensis, n. 2, p. 33-46, 1988.

DOSSETTI, G. Il concetto giuridico dello status religiosus in Sant'Ambrogio. Scienze Storiche, n.18, p. 431-484, 1940.

DUVAL, Y-M. L'originalité du De uirginibus dans le mouvement ascétique occidental: Ambroise, Cyprien, Athanase. In: DUVAL, Y-M. (Ed.). Ambroise de Milan: XVI e centenaire de son élection épiscopale. Paris: Études Augustiniennes, 1974, p. 9-66. LAUGHTON, A. B. From vestal virgin to bride of Christ: elements of a Roman cult in Early Christian asceticism. Studia Antiqua, v. 1, n. 1, p. 3-19, 2001.

LAUGHTON, A. B. Virginity discourse and ascetic politics in the writings of Ambrose of Milan. Dissertation (Doctor of Philosophy) - Department of Religion in Duke University, Durham, 2010.

LÉVI-STRAUSS, C. As estruturas elementares do parentesco. Petrópolis: Vozes, 1982.

LOZANO CORBí, E. Las donaciones nupciales en el derecho romano. lus Fugit, n. 2, p. 221233, 1993.

MCLYNN, N. Ambrose of Milan: Church and court in a Christian capital. Berkeley: University of California Press, 1994.

METZ, R. La consagración de las vírgenes: ayer, hoy, mañana. Madrid: Vision Libros, 2001.

MIRCEA, E. O sagrado e o profano: a essência das religiões. São Paulo: Martins Fontes, 2012.

MORESCHINI, C.; NORELLI, E. História da literatura cristã antiga grega e latina: do concílio de Niceia ao início da Idade Média. São Paulo: Loyola, 2000. 
MORETTI, P. F. La biblia y el discurso de los padres latinos sobre las mujeres: de Tertuliano a Jerónimo. In: BØRRESEN, K. E.; PRINZIVALLI, E. (Ed.). Las mujeres en la mirada de los antiguos escritos cristianos (siglos I-VI). Navarra: Verbo Divino, 2014, p. 145-182.

NATAL VILLAZALA, D. Fugiamus ergo forum: ascetismo y poder en Ambrosio de Milán. León: Universidad de León, 2010.

RAMOS-LISSÓN, D. Introducción. In: AMBROSIO DE MILÁN. Sobre las vírgenes y sobre las viudas. Madrid: Ciudad Nueva, 1999, p. 15-39.

SEIJO IBÁÑEZ, E. La figura femenina en la obra de Ambrosio de Milán. Tesis (Doctorado en Historia). Departamento de Historia y Arqueología de la Universidad de Barcelona, Barcelona, 2017.

SERRATO, M. Ascetismo feminino en Roma. Cádiz: Publicaciones de la Universidad de Cádiz, 1993.

VENTURA DA SILVA. As mulheres e os perigos da cidade: casamento espiritual, virgindade e prostituição segundo João Crisóstomo. In: LEITE, L. R. et al. (Org.). Figurações do masculino e do feminino na Antiguidade. Vitória: PPGL, 2011, p. 33-51.

VIAL-DUMAS, M. Modalidades del matrimonio tardoantiguo y altomedieval en Bizancio y el Occidente cristiano. Byzantion Nea Hellás, n. 34, p. 135-58, 2015. 